EREM 76/4

Journal of Environmental Research Engineering and Management Vol. 76 / No. 4 / 2020 pp. $97-105$

DOI 10.5755/j01.erem.76.4.23508
Structure and Dynamics of Soil Microbial Communities of Natural and Transformed Ecosystems

Received 2019/06

Accepted after revision 2020/10

\title{
Structure and Dynamics of Soil Microbial Communities of Natural and Transformed Ecosystems
}

\section{Olena Demyanyuk, Dmitry Shatsman}

Institute of Agroecology and Environmental Management of NAAS, Metrologichna, 12, 03143 Kyiv, Ukraine

\section{Lyudmyla Symochko*}

Uzhhorod National University, Voloshyna, 32, 88000 Uzhhorod

*Corresponding author: lyudmilassem@gmail.com

Soil microbial communities play an important role in ecosystems functioning and are on the field scale essential for plant nutrition and health. On a larger scale, they contribute to global element cycling. Furthermore, they are involved in the turnover processes of organic matter, the breakdown of xenobiotics and the formation of soil aggregates. An ecological state of soils depends on the structure and activity of soil microorganisms. The results of soil monitoring in various ecosystems in different climatic zones of Ukraine showed a clear trend for the correlation between the agroecological conditions and activity of microbiocenosis. The most significant influence of agricultural activity on the soil microbiota can be observed on the poorly soddy-podzolic and gray forest soils, where the crop cultivation without fertilization resulted in a decrease in the total count of microorganisms by 2.2-4.5 times. Application of agricultural measures aimed at achieving maximum productivity, specifically the combination of mineral, organic and biological fertilizers, contributes to an average 1.3-4.1 times increase in the total count of microorganisms in the soil, compared with non-fertilized variants. Soils with low content of organic matter and acidic medium, soddy-podzolic and gray forest soils were characterized by a high number of micromycetes, $136-185 \times 10^{3} \mathrm{CFU} \cdot \mathrm{g}^{-1}$ soil, and a relatively low number of eutrophic and nitrogen-fixing microorganisms. The soil of natural ecosystems is characterized by a high total count of the microorganisms with a balanced structure of various ecological-trophic groups and balanced processes of mineralization-immobilization, organic matter decomposition, and humus accumulation.

Keywords: soil, microorganisms, ecosystem, community, monitoring. 


\section{Introduction}

Today, the contradictions between the growing needs of mankind and the limited possibilities of nature are particularly acute. The results of the impact of human activity on the environment have become critical. As a result, degradation of ecosystems, climate change, environmental pollution, depletion of natural resources, reduction and loss of biodiversity are occurring (Anand, 2013; Martin et al., 2016). Anthropogenic load on the environment in Ukraine is several times higher than in developed countries of the world. Particularly negative environmental consequences can be traced in the agrosphere, which occupies more than $70 \%$ of the territory of Ukraine.

Agricultural activity primarily affects the soil environment changing the direction of biogeochemical cycles of biophilic elements, the content and composition of organic matter, density and soil structure, water and air regime, etc. Under these conditions, there are changes in the structure of microbial communities, the direction of microbiological processes and biological activity of the soil (Sun et al., 2016; Deng et al., 2019). The biological activity of soils indicates the ability of the soil to perform its functions and it is crucial in ensuring the sustainability of ecosystems (Nannipieri et al., 2017; Yang, et al., 2018). Changing any function of the soil reduces its quality and value, and ability to ensure the productivity of agrocenosis. The ecological status of the soil is characterized by qualitative and quantitative changes in the structure of microbial cenosis and the ratio of the number of microorganisms of certain ecological trophic groups, activity of the main biological processes (Symochko, 2020). The impact of agrotechnologies on the microbiocenosis of the soil can be either direct or indirect due to changes in the physical and chemical parameters of the microclimate, energy sources (carbon), the reorganization of the composition of microbial communities and their functional activity (Auffret et al., 2016).

Biological and biochemical studies of soils have a special place in knowledge of the essence of soil fertility, its ecological status and the prediction of the productivity of agrocenosis (Qamar, et al., 2018). Soil fertility management is, first of all, the management of the microbiological processes occurring in it. It is necessary to conduct depth and comprehensive studies of the basic patterns of the formation of microbial communities and their functional activity, depending on edaphic and agrotechnical factors. The aim of the work was to investigate changes in the structure and activity of soil microbial communities in agro-transformed and natural ecosystems of Ukraine.

\section{Methods}

\section{Study sites and soil sampling}

The study was conducted in the Laboratory of Ecology of Microorganisms at the Institute of Agroecology and Environmental Management of National Academy of Agrarian Sciences of Ukraine and in the Laboratory of Water and Terrestrial Ecosystems Monitoring at the Uzhhorod

Table 1. Agrochemical characteristics of soil in stationary field experiments, $0-20 \mathrm{~cm}$

\begin{tabular}{|c|c|c|c|c|c|}
\hline \multirow[b]{2}{*}{$\begin{array}{c}\text { Type of soil } \\
\text { Geographic coordinates }\end{array}$} & \multirow[b]{2}{*}{$\mathrm{pH}$} & \multirow[b]{2}{*}{$\begin{array}{l}\text { Humus, } \\
\%\end{array}$} & \multicolumn{3}{|c|}{ Content, $\mathrm{mg} \cdot \mathrm{kg}^{-1}$ of soil } \\
\hline & & & $\begin{array}{l}\text { Nitrogen which is } \\
\text { easily hydrolyzed }\end{array}$ & $\begin{array}{c}\text { Active } \\
\text { phosphorus }\end{array}$ & $\begin{array}{c}\text { Exchangeable } \\
\text { potassium }\end{array}$ \\
\hline $\begin{array}{l}\text { Chernozem ordinary } \\
\text { N } 48^{\circ} 5^{\prime} 28.972^{\prime \prime} \\
\text { E } 37^{\circ} 39^{\prime} 00.527^{\prime \prime}\end{array}$ & 6.5 & 5.2 & 114 & 98 & 143 \\
\hline $\begin{array}{l}\text { Gray forest } \\
\text { N } 49^{\circ} 11^{\prime} 19.175^{\prime \prime} \\
\text { E } 28^{\circ} 21^{\prime} 16.549^{\prime \prime}\end{array}$ & 4.2 & 1.7 & 76 & 174 & 115 \\
\hline $\begin{array}{l}\text { Soddy-podzolic } \\
\text { N } 51^{\circ} 7^{\prime} 00.207^{\prime \prime} \\
\text { E } 31^{\circ} 10^{\prime} 07.111^{\prime \prime}\end{array}$ & 4.9 & 1.1 & 74 & 170 & 68 \\
\hline
\end{tabular}


National University. The initial data for the analysis, calculations and mathematical analysis were the results of multi-year studies of soil microbiocenoses in stationary field experiments of the National Academy of Agrarian Sciences of Ukraine during 2001-2015. Three types of soil were studied in different natural and climatic zones of Ukraine (Steppe zone - Donetsk region, Forest-steppe - Vinnytsia region, and Polissya - Chernihiv region).

The soil sampling was carried out by standard methods (ISO 10381-6:1993) in multi-year field experiments, the characteristics of which are given in Table 1. For comparison, the soil was studied in natural ecosystems (fallow land).

The soil samples of the agroecosystems were selected from the $0-20 \mathrm{~cm}$ layer of the plants over the period when the system reached its climax - stable, balanced state. All samples were prepared using the unified procedure: they were air dried and grounded to $<3 \mathrm{~mm}$ in size; visible plant and mesofauna residues were removed. Experiments were performed in 5 -fold repetition.

\section{Number of soil microorganisms}

For the microbiological analyses, we selected the soil samples from each variant of the experiment and an abandoned field in 5-fold replication and prepared an average sample. Batches of $10 \mathrm{~g}$ each were put on sterile mortar and then the microorganisms were separated from the soil particles using the method of Zviahyntsev (1991). We prepared 10-fold solutions of the output soil suspension, which were used for inoculations to the elective media for each ecological-trophic or taxonomic group of microorganisms. The quantitative compound of the microorganisms of the main ecological-trophic and taxonomic groups in soil was determined using the methods of inoculating the soil suspension to standard growth media, which are generally accepted in soil microbiology (Zviahyntsev, 1991): the total number of microorganisms on peptone-glucose agar with soil extraction (PGA), bacteria which use organic nitrogen $\left(\mathrm{N}_{\text {org }}\right)$ to meat infusion agar (MIA), streptomyces and bacteria which use mineral nitrogen $\left(N_{\text {min }}\right)$ to starch-and-ammonia agar (SAA), the number of pedotrophs to soil agar (SA), nitrogen-fixing microorganisms on the non-nitrogenous media of Ashby and Vinogradsky, oligotrophs on purified agar (PA), micromycetes to Czapek-Dox agar. After the inoculation to the media, the bacteria were incubated at the temperature of $28^{\circ} \mathrm{C}$ during $5-14$ days. The colonies which grew in these media were calculated on the assumption that one colony is formed from one vital cell. The results of measuring the number of microorganisms grown on the nutrient media were expressed in colony forming units (CFU) per $1 \mathrm{~g}$ of dry soil. For this purpose, we determined the moisture of the soil samples for the experiments using the thermostat-gravimetric analysis, and recalculated the obtained number of colonies taking into consideration the coefficient of moisture and solution of the soil suspension. The inoculations were repeated three times, and the obtained data were analyzed using mathematical statistics, calculating the confidence interval in the number of microorganisms.

The taxonomic structure of the microbial communities was determined as a percentage of such taxa: bacteria, streptomyces and micromycetes (Strickland and Rousk, 2010).

\section{Direction of soil microbiological process}

The direction of microbiological processes in the soil was determined by the appropriate coefficients (Andreyuk and Valagurova, 1992):

coefficient of mineralization $\left(K_{\min }\right)$ was calculated by the ratio of the number of microorganisms immobilizing the mineral forms of nitrogen $\left(\mathrm{C}_{\mathrm{SAA}}\right)$ to the number of organotrophs $\left(\mathrm{C}_{\mathrm{MIA}}\right)$ by the formula: $\mathrm{K}_{\min }=\mathrm{C}_{\mathrm{SAA}} / \mathrm{C}_{\mathrm{MIA}}$; coefficient of oligotrophity $\left(K_{0}\right)$ was calculated by the ratio of the number of microorganisms, which are able to absorb nutrients from very rarefied solutions to the total number of eutrophic microorganisms by the formula: $\mathrm{K}_{\mathrm{ol}}=\mathrm{C}_{\mathrm{PA}} /\left(\mathrm{C}_{\mathrm{SAA}}+\mathrm{C}_{\mathrm{MIA}}\right)$;

coefficient of pedotrophity $\left(K_{\text {ped }}\right)$ was calculated as the ratio of the number of pedotrophic microorganisms $\left(C_{S A}\right)$ to the number of microorganisms using organic nitrogen $\left(\mathrm{C}_{\text {MIA }}\right): \mathrm{K}_{\text {ped }}=\mathrm{C}_{\mathrm{SA}} / \mathrm{C}_{\text {MIA }}$;

coefficient transformation of organic matter $\left(\mathrm{K}_{\text {tom }}\right)$ was calculated by the formula: $\mathrm{K}_{\mathrm{tom}}=\left(\mathrm{C}_{\mathrm{MIA}}+\mathrm{C}_{\mathrm{SAA}}\right) \times$ $\left(\mathrm{C}_{\mathrm{MIA}} / \mathrm{C}_{\mathrm{SAA}}\right)$.

\section{Biodiversity of soil microbiocenosis}

Biodiversity of sol microbiocenosis was calculated according to the Shannon index and the Simpson index 
(Shannon index, Simpson index) (Magurran, 1988).

Formulas used to calculate diversity measures analyzed: Shannon diversity index $(\mathrm{H})$ :

$$
\mathrm{H}=-\sum P_{i} \ln \left(P_{i}\right)
$$

where $P_{i}$ - is the proportion of individuals belonging to species $i$;

Simpson diversity index (D):

$$
\mathrm{D}=1-\sum P_{i}^{2}
$$

\section{Data Analysis}

The results of the experimental studies were statistically analyzed using the Microsoft Excel program package. The tests were performed in 5-10 times replication. We determined the mean values $(\mathrm{x})$ and their standard deviations (SD). The level of significance selected for the study was $\mathrm{P}<0.05$.

\section{Results and Discussion}

The results of many years of research have shown that the total number of microorganisms in the soil depends on the type of ecosystem (Table 2). At the same time, significant fluctuations in the structure of microbiocenoses of soils of natural ecosystems have not been fixed. The smallest pool of microorganisms was in the soddy-podzolic soils, which correlates with low content of organic matter and stocks of biogenic nutrients.

The use of soil in agriculture and the application of various agrotechnologies violate the structure of microbial cenosis and its functions (Habig and Swanepoel, 2015). Our studies have shown that the most important impact of agricultural activity on soil microbiota was on lowgrowth soils, i.e., turf-podzolic and gray forest, where prolonged cultivation of non-fertilized agricultural crops led to a decrease in the total pool of microorganisms 2.2-4.5 times. In the chernozem, the total number of microorganisms was reduced only by 1.9 times. Soils with

Table 2. Total pool of microorganisms in soils of natural and transformed ecosystems, $\times 10^{6} \mathrm{CFU}^{-1}$ of dry soil

\begin{tabular}{l|c|c}
\hline \multicolumn{1}{|c|}{ Type of soil } & $\begin{array}{c}\text { natural ecosystems } \\
\text { (fallow land) }\end{array}$ & $\begin{array}{c}\text { Transformed ecosystems - Agroecosystem } \\
\text { (arable soil) }\end{array}$ \\
\hline Chernozem ordinary & $28.6 \pm 0.4$ & $\frac{14.9 \pm 0.3}{19.3 \pm 0.3}$ \\
\hline Gray forest & $6.2 \pm 0.2$ & $\underline{2.8 \pm 0.2}$ \\
\hline Soddy-podzolic & $5.4 \pm 0.2$ & $\frac{1.2 \pm 0.1}{4.9 \pm 0.2}$ \\
\hline
\end{tabular}

Note: numerator - without fertilizers; denominator - a variant with balanced doses of fertilizers and other agrotechnical measures that ensure maximum productivity. The data are statistically significant, $P<0.05, x \pm S D, n=6$.

high content of organic matter, having a higher buffering capacity, are more resistant to the vulnerability of soil microbiota to different agro-technical measures.

The application of a balanced combination of different types of mineral, organic and biological fertilizers positively influenced soil microbiota. An increase in the total number of microorganisms was observed on average by 1.3-4.1 times in comparison with the backgrounds without fertilization. The greatest positive effect of agro measures on microbiocenosis was in soddy-podzolic soils. That is, such soils are most susceptible to any anthropogenic impact. Soils of agroecosystems were characterized by a decrease in the general pool of microorganisms and impoverished microbial diversity (Table 3). In assessing the taxonomic diversity of microbial community, the Shannon index shows a greater diversity of soil microbiome in natural ecosystems, and, hence, higher resistance to various environmental factors. The ability to self-regulate and efficient use of energy resources of natural ecosystems is ensured by the numerous trophic levels and high adaptive potential of microorganisms that are part of the microbiocenosis, that is, 
Table 3. Diversity indices for soil microbial community

\begin{tabular}{l|c|c|c|c}
\hline \multirow{2}{*}{\multicolumn{1}{c}{ Type of soil }} & \multicolumn{2}{c|}{$\begin{array}{c}\text { natural ecosystems } \\
\text { (fallow land) }\end{array}$} & \multicolumn{2}{c}{$\begin{array}{c}\text { Transformed ecosystems - Agroecosystem } \\
\text { (arable soil) }\end{array}$} \\
\cline { 2 - 5 } & Shannon (H) & Simpson (D) & Shannon (H) & Simpson (D) \\
\hline Chernozem ordinary & $6.21 \pm 0.29$ & $0.0200 \pm 0.0016$ & $3.11 \pm 0.12$ & $0.1231 \pm 0.0059$ \\
\hline Gray forest & $3.43 \pm 0.12$ & $0.1530 \pm 0.0071$ & $1.96 \pm 0.10$ & $0.2108 \pm 0.0063$ \\
\hline Soddy-podzolic & $2.64 \pm 0.11$ & $0.1780 \pm 0.0076$ & $1.64 \pm 0.10$ & $0.2530 \pm 0.0061$ \\
\hline
\end{tabular}

The data are statistically significant, $P<0.05, x \pm S D, n=5$.

conditions are created for compensatory reactions in the event of violation of certain chains in the system.

In the soil of agroecosystems, there was a decrease in biodiversity and the formation of a homogeneous microbial complex with a high degree of dominance of certain morphotypes. In studies by Zhou et al. (2015), the continued introduction of inorganic fertilizers into chernozem soil has led to a reduction in the biological diversity and the number of bacteria. Detailed study of the quantitative composition of microorganisms of the main ecological trophic and taxonomic groups showed a clear differentiation of their content in natural biocenoses depending on the type of soil (Fig. 1).

Fig. 1. Quantitative characteristics of microorganisms of major groups in different types of soil. A - chernozem ordinary; $B$ - gray forest; $C$ soddy-podzolic. The data are statistically significant, $P<0.05, x \pm S D, n=6$.
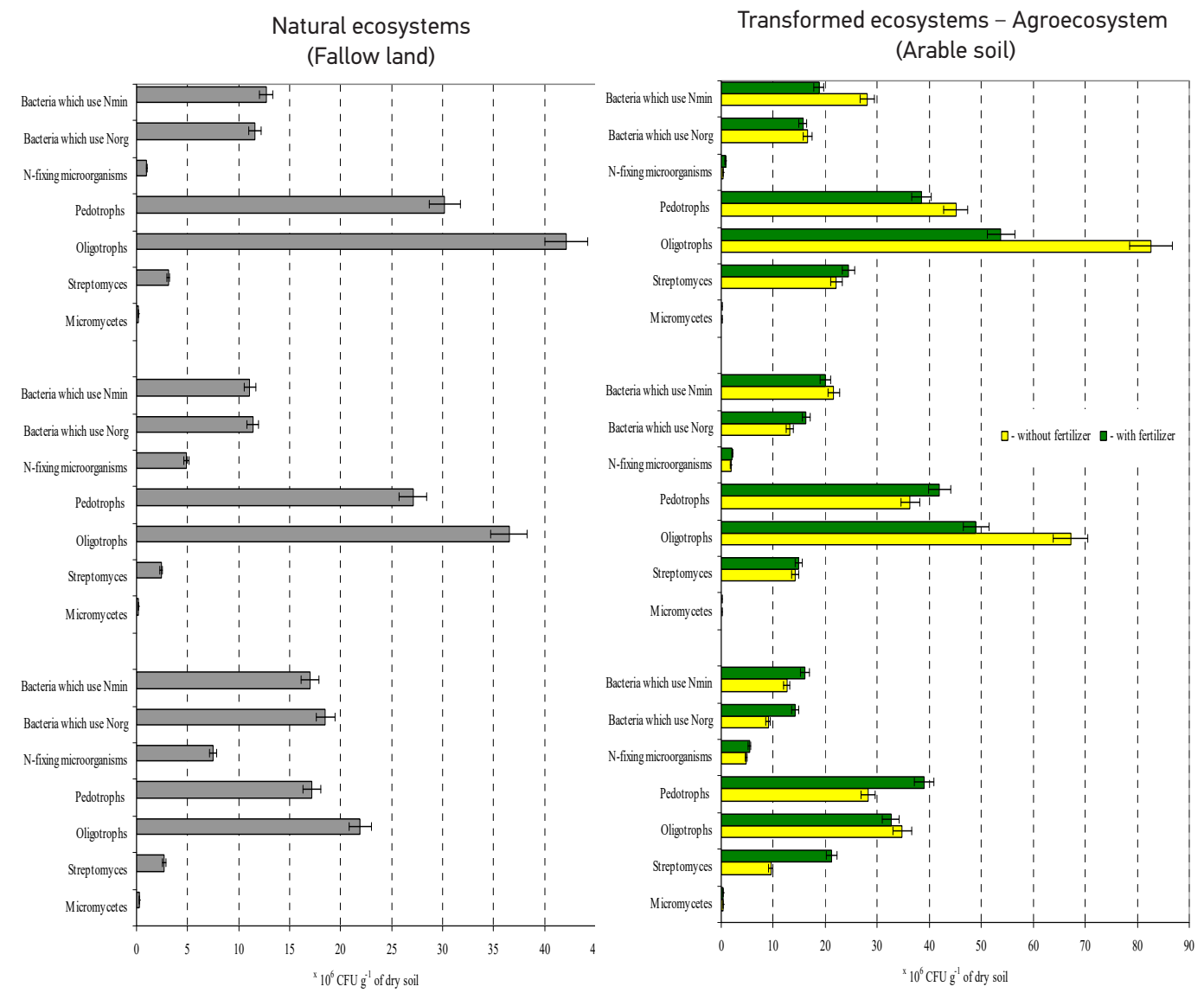
Soil with low content of SOM and acidic reaction $(\mathrm{pH}<5)$ is characterized by a high content of mycelial organisms and bacteria using mineral nitrogen $\left(\mathrm{N}_{\text {min }}\right)$, in particular, in soddy-podzolic soils, a high number of micromycetes $\left(18-5 \times 10^{3}\right.$ $\left.\mathrm{CFU} \mathrm{g}^{-1}\right)$ and streptomyces $\left(3-1 \times 10^{6} \mathrm{CFU} \mathrm{g}^{-1}\right)$ and a relatively small amount of eutrophic and nitrogen-fixing microorgan-

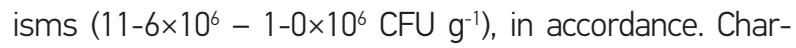
acteristic for chernozem is the low content of pedotrophic and oligotrophic microorganisms (17-2; 21-9 ×10 $\left.\mathrm{CFU} \mathrm{g}^{-1}\right)$, high numbers of bacteria using $\mathrm{N}_{\text {org }}$ and $\mathrm{N}_{\text {min }}\left(18-5 \times 10^{6}\right.$ and $\left.17-0 \times 10^{6} \mathrm{CFU} \mathrm{g}^{-1}\right)$, nitrogen fixing $\left(7.5 \times 10^{6} \mathrm{CFU} \mathrm{g}^{-1}\right)$ and $\mathrm{mi}-$ cromycetes $\left(260 \times 10^{3} \mathrm{CFU} \mathrm{g}^{-1}\right)$. In comparison with natural ecosystems in arable soils the number of streptomyces increased significantly by 5.7-7.5 times and bacteria using $\mathrm{N}_{\min }$ by 1.8-1.9 times. The highest vulnerability of the soil microbial ecosystem was in variants without the application of any nutrients into the soil. Prolonged soil management without additional fertilization resulted in a decrease in the content of agronomically useful microorganisms, especially nitrogen-fixing microorganisms by $1.6-2.7$ times. Under these conditions, in gray forest and soddy-podzolic soils, the number of oligotrophs and bacteria using $N_{\text {min }}$ was increased almost twice, compared with the analogue of the soil in a natural ecosystem. This indicates intensification of the destruction processes of soil organic matter (SOM) and the decomposition of humus substances. The enrichment of gray forest and soddy-podzolic soils with nutrients has led to the intensification of the growth of the number of bacteria using $\mathrm{N}_{\text {org }}$ by $40 \%$, and micromycetes by $30 \%$, and streptomyces at 6.2-7.9 times. Application of fertilizers in chernozem of an agrotransformed ecosystem resulted in no significant differences $(P<0.05)$ between the number of bacteria using $\mathrm{N}_{\text {min }}$ and $\mathrm{N}_{\text {org }}$ compared with the natural analogue, although the reduction was $5 \%$ and $23 \%$, respectively. However, the number of streptomycetes increased by almost 8 times. In the soil of agroecosystems, not only the reduction of the content of organic matter and its redistribution in the soil profile were fixed, but also the changes in the availability of nutrients and a pool of basic nutrients. This creates new conditions for soil microorganisms and leads to changes in the structure of their community (Sun et al., 2018). Therefore, an important direction is the study of the impact of agricultural land use on the soil microbiome, the dependence of the number and diversity of microbiota on environmental and human factors that determine the stability of agricultural soils (Patyka and Symochko, 2013; Symochko, 2020).
It has been established that the edaphic conditions and factors that determine the soil fertility $(\mathrm{SOC}, \mathrm{C} / \mathrm{N}$, NPK content in the soil) correlate with the structure of the microbial group, the dependence of the number and diversity of microbiota on the environmental and human factors that determine the stability of agricultural soil (Symochko et al., 2019). Analysis of the taxonomic structure of microbiocenoses of the studied soils (Fig. 2) showed that the soil of biocenoses was characterized by a more stable ratio of bacteria, streptomycetes and micromycetes: for chernozem ordinary - 94\%:4.5\%:1.1\%, gray forest - 82.9\%:15.3\%:1.8\%, soddy-podzolic - 77.2\%:20.3\%:2.5\%, respectively. Bacteria are commonly found in soils rich in SOM, while relatively large amounts of saprophytic fungal communities tend to increase when soil fertility is reduced.

The chernozem soil of the agroecosystem has a more stable and balanced structure of microbiocenosis than soddy-podzolic and gray forest. The percentage of bacterial organisms in it is at $90 \%$, and only the use of mineral fertilizers reduces it to $88 \%$. The growth of the proportion of micellar organisms occurs in the long-term application of mineral fertilizers, both individually and in combination with organic fertilizers. This is due to an increase in the acidity of the soil, but, as well known, micromycetes prefer acidic soils (Cheng et al., 2015; Zhang et al., 2016).

The part of micromycetes and streptomyces in the taxonomic structure of soddy-podzolic soils with an acidic reaction and a low content of SOM was higher, respectively, by 2.3 and 4.5 times in comparison with chernozem. Due to the lack of organic matter in the soil, the microbial community is restructured in the direction of the growth of the micellar organisms as more resistant to the environmental and anthropogenic factors.

According to the ratio of the number of microorganisms of certain ecological trophic groups, the direction of microbiological processes in the soil was analyzed (Table 4). In chernozem soil of natural ecosystems, the activity of mineralization processes, oligotrophy and pedotrophy is low (microbiological coefficient $<1$ ).

It was established that irrespective of the edaphic conditions in the soil of agroecosystems on non-fertilized backgrounds the activity of mineralization processes increased by 1.5-1.7 times, as well as coefficient of oligotrophy and pedotrophy by 1.1-3 times, indicating a 
Fig. 2. Community composition of soil bacteria, streptomyces and micromycetes in different soil. A - natural ecosystems (Fallow land), B agroecosystem (Arable soil). The data are statistically significant, $P<0.05, x \pm S D, n=6$.

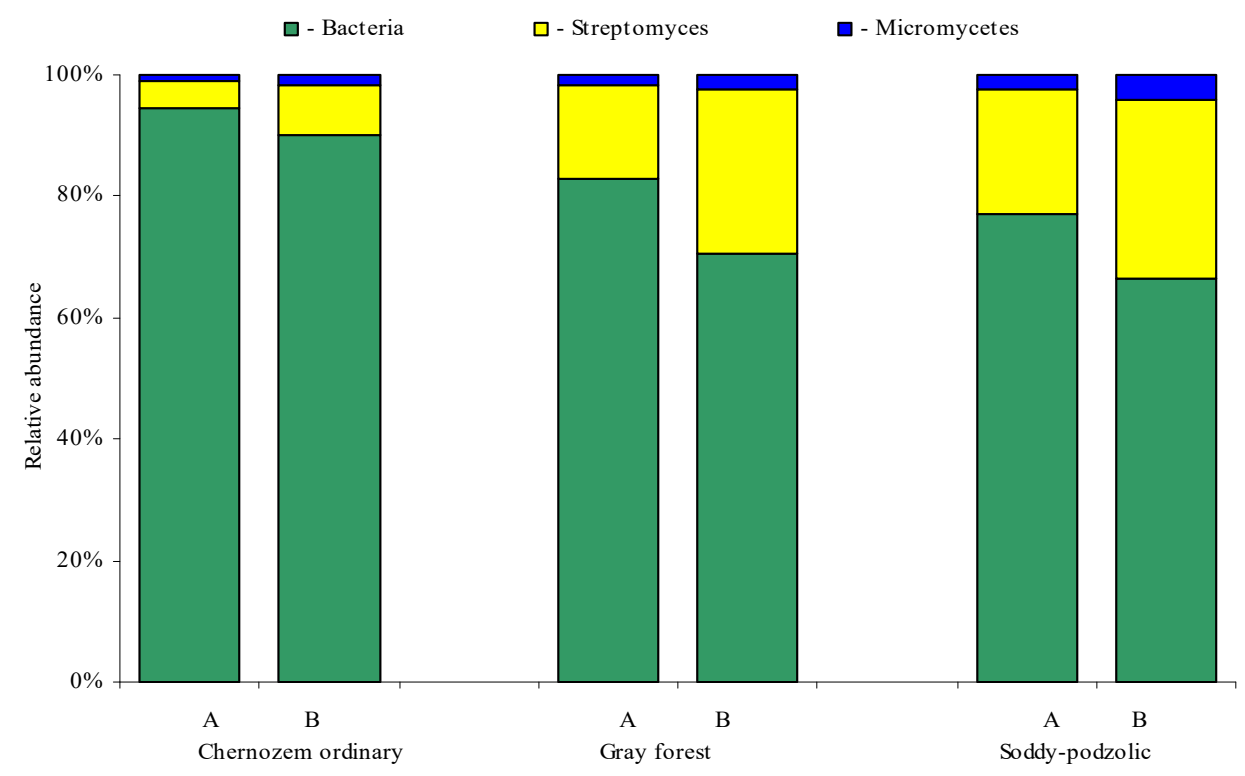

Table 4 Direction of microbiological processes in the soil of natural (virgin land) and transformed (arable soil) ecosystems

\begin{tabular}{|c|c|c|c|c|}
\hline \multirow[b]{2}{*}{ Treatment } & \multicolumn{4}{|c|}{ Coefficient } \\
\hline & $\begin{array}{c}\text { Mineralization } \\
\mathrm{K}_{\min }\end{array}$ & $\begin{array}{c}\text { Oligotrophity } \\
\mathrm{K}_{\mathrm{ol}}\end{array}$ & $\begin{array}{c}\text { Pedotrophity } \\
\mathrm{K}_{\mathrm{ped}}\end{array}$ & $\begin{array}{c}\text { Transformation of } \\
\text { organic matter } \\
\mathrm{K}_{\mathrm{tom}}\end{array}$ \\
\hline \multicolumn{5}{|c|}{ Chernozem ordinary } \\
\hline Virgin land & 0.92 & 0.62 & 0.93 & 38.63 \\
\hline Arable soil & $\frac{1.40}{1.13}$ & $\frac{1.61}{1.08}$ & $\frac{3.13}{2.75}$ & $\frac{15.43}{26.72}$ \\
\hline \multicolumn{5}{|c|}{ Gray forest } \\
\hline Virgin land & 0.97 & 1.62 & 2.38 & 23.11 \\
\hline Arable soil & $\frac{1.64}{1.23}$ & $\frac{1.93}{1.35}$ & $\frac{2.75}{2.58}$ & $\frac{21.27}{29.58}$ \\
\hline \multicolumn{5}{|c|}{ Soddy-podzolic } \\
\hline Virgin land & 1.09 & 1.73 & 2.60 & 22.20 \\
\hline Arable soil & $\frac{1.69}{1.20}$ & $\frac{1.85}{1.56}$ & $\frac{2.72}{2.45}$ & $\frac{26.41}{28.81}$ \\
\hline
\end{tabular}

Note: numerator - without fertilizers; denominator - a variant with balanced doses of fertilizers and other agrotechnical measures that ensure maximum productivity. The data are statistically significant, $P<0.05$. 
deterioration of the nutritional regime and the development of processes destruction of organic matter.

In particular, as our studies showed, the application of mineral fertilizers into chernozem soils has activated the development of pedotrophic and oligotrophic microorganisms and microorganisms using $N_{\min }$ by $1.3-1.5$ times (Demyanyuk et al., 2019). At the same time, growth of values of coefficients $\mathrm{K}_{\min }$ and $\mathrm{K}_{\text {ped }}$ was fixed for $18 \%$ and $9 \%$, respectively. The application of balanced doses of fertilizers reduced the activity of mineralization of organic matter in the soil by 19-29\% and the oligotrophy by 16-33\%. Also, there was active development of zymogenic microbiota, which decomposes fresh organic compounds and plant remains; the value of the coefficient pedotrophy decreased by $8-12 \%$. The transformation of organic compounds increased by $10-70 \%$ compared with the non-fertilized variant, and this process depended on the type of soil and the type of fertilizer.

\section{Conclusions}

The soil of natural ecosystems is characterized by a high content of the total number of microorganisms with a

\section{References}

Anand S.V. (2013) Global environmental issues. Open Access Scientific Reports 2(2): 632. https://doi.org/10.4172/scientificreports.632 https://doi.org/10.1109/JSSC.2013.2242392

Andreyuk E.I. and Valagurova E.V. (1992) Fundamentals of the ecology of soil microorganisms. Kyiv, Ukraine (in Russian).

Auffret M.D., Karhu K., Khachane A., et al. (2016) The role of microbial community composition in controlling soil respiration responses to temperature. PloS ONE 11(10): e0165448. https:// doi.org/10.1371/journal.pone.0165448

Cheng F., Wei X., Hou L., et al. (2015) Soil fungal communities of montane natural secondary forest types in China. J. Microbiol. 53: 379-389. https://doi.org/10.1007/s12275-015-4722-3

Demyanyuk O., Symochko L., Hosam E.A.F. Bayoumi Hamuda, et al. (2019) Carbon pool and biological activities of soils in different ecosystems. International Journal of Ecosystems and Ecology Science 9(1): 189-200. https://doi.org/10.31407/ijees9122 balanced structure of various ecological trophic groups, as well as the balance of mineralization, pedotrophy and transformation of organic matter. Regardless of the type of soil in the transformed ecosystems, due to the application of agro-measures, significant changes in the structure of microbial cenosis and its functioning were observed. The chernozem soil of the agroecosystem has a more stable and balanced structure of microbiocenosis than soddy-podzolic and gray forest. The percentage of bacterial organisms was $90 \%$. Application of exogenous mineral substances activates the processes of soil mineralization. The organic fertilizer system in the soil increased the number of organotrophic microorganisms, and $\mathrm{K}_{\min }$ decreased by $26-29 \%$, while the content of organic matter of the soil increased by $33-37 \%$, which indicates about favourable conditions for the accumulation of humus in the soil. In the soil with low SOM content, the mineralization activity $\left(\mathrm{K}_{\min }\right.$ increased by $\left.5-18 \%\right)$, oligotrophy and pedotrophy increased by $2.2-2.8$ times in comparison with chernozem. Transformation of organic matter in chernozem was more active by 1.7 times and correlated with SOM content. The most important influence of agricultural activity on soil microbiota can be traced in soils with low content of SOM.

Deng J., Yin Y., Luo J., et al. (2019) Different revegetation types alter soil physical-chemical characteristics and fungal community in the Baishilazi Nature Reserve. PeerJ 6: e6251. https:// doi.org/10.7717/peerj.6251

Habig J. and Swanepoel C. (2015) Effects of conservation agriculture and fertilization on soil microbial diversity and activity. Environments 2: 358-384. https://doi.org/10.3390/environments 2030358

ISO 10381-6 : 1993. Soil quality. Sampling. Part 6: Guidance on the collection, handling and storage of soil for the assessment of aerobic microbial processes in the laboratory.

Magurran A.E. (ed.) (1988) Diversity indices and species abundance models. In: Ecological Diversity and Its Measurement (London: Springer), 7-45. https://doi.org/10.1007/978-94-015-7358-0_2

Martin J-L., Maris V. and Simberloff D.S. (2016) The need to respect nature and its limits challenges society and conservation 
science. Proc. Natl. Acad. Sci 13(22): 6105-6112. https://doi. org/10.1073/pnas.1525003113

Nannipieri P., Ascher J., Ceccherini M.T., et al. (2017) Microbial diversity and soil functions. European Journal of Soil Science 68(1): 12-26. https://doi.org/10.1111/ejss.4_12398

Patyka V.P. and Symochko L.Y. (2013) Soil microbiological monitoring of natural and transformed ecosystems in the trans-Carpathian region of Ukraine. Mikrobiol. Z. 75(2): 21-31 (in Ukraine). Qamar S.U.R., Haroon and Saif A. (2018) An overview on microorganisms contribute in increasing soil fertility. Biomed J Sci \& Tech Res 2(1). https://doi.org/10.26717/BJSTR.2018.02.000641 https://doi.org/10.26717/BJSTR.2017.01.000641

Sun R., Li W., Dong W., et al. (2018) Tillage changes vertical distribution of soil bacterial and fungal communities. Frontiers in microbiology 9: 699. https://doi.org/10.3389/fmicb.2018.00699

Strickland M.S. and Rousk J. (2010) Considering fungal:bacterial dominance in soils - Methods, controls, and ecosystem implications. Soil Biol. Biochem. 42(9): 1385-1395. https://doi. org/10.1016/j.soilbio.2010.05.007
Symochko, L., Mariychuk, R., Demyanyuk, O., Symochko, V. (2019) Enrofloxacin in Agroecosystems: Uptake by Plants and Phytotoxical Effect. International Council of Environmental Engineering Education - \&amp;quot;Technologies of Environmental Protection\&amp;quot; - Proceedings, 250-253 https://doi. org/10.1109/ICTEP48662.2019.8968989

Symochko L. (2020) Soil microbiome: diversity, activity, functional and structural successions. International Journal of Ecosystems and Ecology Sciences (IJEES) 10 (2): 277-284. https:// doi.org/10.31407/ijees10.206

Zhang T., Wang N.F., Liu H.Y., et al. (2016) Soil pH is a key determinant of soil fungal community composition in the Ny-Ålesund Region, Svalbard (High Arctic). Front. Microbiol. 7: 227. https://doi.org/10.3389/fmicb.2016.00227

Zhou J., Guan D.W., Zhou B.K., et al. (2015) Influence of 34-years of fertilization on bacterial communities in an intensively cultivated black soil in northeast China. Soil Biol. Biochem. 90: 4251. https://doi.org/10.1016/j.soilbio.2015.07.005

Zviahyntsev D.H. (1991) Methods of soil microbiology and biochemistry, Moscow State University. Moscow, Russian (in Russian). 